\title{
Highly Active and Durable Transition Metal-Coordinated Nitrogen Doped Carbon Electrocatalyst for Oxygen Reduction Reaction in Neutral Media
}

\author{
Kriangsak Ketpang ${ }^{1,2}$, Apikom Boonkitkoson ${ }^{1}$, Nattawan Pitipuech ${ }^{3}$, Chedthawut Poompipatpong ${ }^{2,4}$, Jakkid Sanetuntikul ${ }^{2,3^{*}}$ \\ and Sangaraju Shanmugam ${ }^{5}$ \\ ${ }^{1}$ Faculty of Science Energy and Environment, King Mongkut's University of Technology North Bangkok, Rayong Campus, Thailand \\ ${ }^{2}$ Automotive Eco-Energy and Industrial Product Standard Research Center, Science and Technology Research Institute, King \\ Mongkut's University of Technology North Bangkok, Thailand \\ ${ }^{3}$ Faculty of Engineering and Technology, King Mongkut's University of Technology North Bangkok, Rayong Campus, Thailand \\ ${ }^{4}$ College of Industrial Technology, King Mongkut's University of Technology North Bangkok, Thailand \\ ${ }^{5}$ Department of Energy Systems Science, Daegu Gyongbuk Institute of Science and Technology (DGIST), Korea
}

\begin{abstract}
The major technical obstacles in commercialization of microbial fuel cell technology are the sluggish kinetic, high cost, and poor durability of an air cathode electrocatalyst. This research aimed to synthesize the highly active, stable and low cost non-precious metal catalyst to replace the expensive Pt electrocatalyst using a simple, low cost and scalable method. The $\mathrm{Fe}_{3} \mathrm{C}$ and $\mathrm{Fe}-\mathrm{N}-\mathrm{C}$ catalysts were prepared by direct heating the precursors under autogenic pressure conditions. X-ray diffraction pattern revealed the phase of $\mathrm{Fe}_{3} \mathrm{C}$ sample was cohenite $\mathrm{Fe}_{3} \mathrm{C}$ and graphitic carbon, while the phase of $\mathrm{Fe}-\mathrm{N}-\mathrm{C}$ catalyst was only graphitic carbon. The morphology of the synthesized catalysts was a highly porous structure with nanoparticle morphology. The surface area of the $\mathrm{Fe}_{3} \mathrm{C}$ and the $\mathrm{Fe}-\mathrm{N}-\mathrm{C}$ catalysts was 295 and $377 \mathrm{~m}^{2} \mathrm{~g}^{-1}$, respectively. The oxygen reduction reaction (ORR) activity of Fe-N-C catalyst was more active than $\mathrm{Fe}_{3} \mathrm{C}$ catalyst. The ORR performance of $\mathrm{Fe}-\mathrm{N}-\mathrm{C}$ catalyst exhibited about 1.6 times more superior to that of the noble $\mathrm{Pt} / \mathrm{C}$ catalyst. In addition, the $\mathrm{Fe}-\mathrm{N}-\mathrm{C}$ catalyst was durable to operate under neutral media. Thus, a novel autogenic pressure technique was a promising method to effectively prepare an highly active and durable non-precious metal catalyst to replace the precious $\mathrm{Pt} / \mathrm{C}$ catalyst.
\end{abstract}

\section{Introduction}

Microbial fuel cells (MFCs) is a bio-electrochemical device directly extracting electrical energy during wastewater purification process [1-3]. The electrical energy generating from MFC has been beneficially utilized for powering small electronic devices such as sensors, pumps, clocks and mobile phones [1]. Basically, wastewater is bio-catalytically oxidized into protons and electrons at the anode. Electrons travel through an external wire to the cathode electrode, while protons diffuse though an electrolyte membrane to the cathode. Air supplied at the cathode and oxygen undergoes electrochemical oxygen reduction reaction (ORR) by combining protons and electrons producing water. MFC is suitably operated under the $\mathrm{pH}$ range of $6-8$ and at room temperature due to the optimum condition of the bio-bacterial catalyst [2]. However, this operating condition leads to slow kinetic of the ORR at the air cathode, yielding low MFC performance [3]. Thus, substantial amount of catalyst is loaded at the air cathode electrode so as to accelerate the ORR under MFC operating condition. The fact that the precious platinum nanoparticles supported on carbon $(\mathrm{Pt} / \mathrm{C})$ has been widely investigated as the most active ORR electrocatalyst for polymer electrolyte membrane fuel cells operated under acidic and alkaline environments [3]. Nevertheless, a significant disadvantage of the utilization of Pt catalyst is high cost and high ORR overpotential under the wastewater treatment conditions that is one of the main major hindering the widespread application of the MFC technology [3]. Furthermore, the surface of Pt electrocatalyst is easily deactivated by the poison of the contaminant from the wastewater, resulting in noticeable decrease of the air cathode activity, deteriorating the MFC efficiency [3]. For this reason, significant research has been focused on the development of highly active and durable non-precious ORR catalyst to replace the expensive Pt catalyst and to improve the MFC performance as well [1-3].

Carbon-based materials in the form of nanoparticle, nanosheet, nanotube and nanofiber have been potentially investigated as the non-precious ORR catalyst owing to outstanding properties: low cost, excellent electrical conductivity, biocompatibility, high surface area, easy process ability and good mechanical strength $[4,5]$. However, the ORR performance of the carbonaceous catalyst was much poorer than the precious $\mathrm{Pt} / \mathrm{C}$ catalyst $[4,5]$. To improve the electrochemical ORR performance

\footnotetext{
* Corresponding author: jakkid.s@eat.kmutnb.ac.th
} 
of carbon catalyst, heteroatoms such as nitrogen, boron, phosphorus and sulfur atoms were incorporated into the carbon framework [6-9]. Among dopants, nitrogen atom (N) that is similar size and slightly higher electronegativity value than carbon atom, has been experimentally accepted as the most efficient dopant to decrease the ORR overpotential [10-11]. Incorporation of $\mathrm{N}$ atom into carbon framework induces the charge of carbon atoms next to $\mathrm{N}$ doped atom to be slightly positive. The charge redistribution in the doped catalyst proficiently facilitates the ORR during fuel cell operation [10-11]. The overpotential of the $\mathrm{N}-\mathrm{C}$ catalyst was dramatically less than the non-doped catalyst [6-7]. Compared to the noble $\mathrm{Pt} / \mathrm{C}$ catalyst, the electrochemical ORR performance was still lower $[6,7]$. To overcome this challenge, an inexpensive first row transition metals $(\mathrm{M}=\mathrm{Mn}, \mathrm{Fe}, \mathrm{Co}, \mathrm{Ni})$ was coordinated with nitrogen doped carbon framework [12-17]. These catalysts are commonly known as M-N-C electrocatalyst. Kodali et al. [15] synthesized iron aminoantipyrine (Fe-AApyr) electrocatalyst by calcination of iron nitrate mixed aminoantipyrine in the presence of silica template at $950^{\circ} \mathrm{C}$ under ultrapure nitrogen atmosphere [15]. The ORR performance of Fe-AApyr electrocatalyst was compared with that of graphene nanosheet and activated carbon electrocatalysts under neutral media environment [15]. The Fe-AApyr sample exhibited the most efficient ORR active catalyst under neutral media due to the formation of $\mathrm{Fe}-\mathrm{N}_{4}$ active site [15]. Birry et al. [16] prepared Fe-N-C catalysts by pyrolyzing carbon black mixed various $\mathrm{Fe}$ precursors (Fe-acetate (FeAc), Fe-porphyrin, Fe-phthalocyanine $(\mathrm{FePc}))$ at high temperature and under ammonia and/or $\mathrm{Ar}$ atmosphere [16]. It was found that $\mathrm{Fe}-\mathrm{N}-\mathrm{C}$ catalyst derived from macrocycles structure provided the best ORR performance under neutral solution [16]. In addition, the synthesized Fe-N-C catalyst exhibited more active and durable ORR performance than that of the expensive $\mathrm{Pt} / \mathrm{C}$ electrocatalyst under MFC operation condition [16]. The highly active and durable ORR performance of Fe-N-C electrocatalyst were mainly attributed to the formation of $\mathrm{Fe}-\mathrm{N}_{4}$ moieties, high surface area and high electrical conductivity [16]. Based on the discovery of M-N-C catalyst, an inert and/or ammonia atmosphere are essentially required to fabricate highly active catalyst. However, fabrication of catalyst under inert atmosphere may prevent the complete decomposition of the carbonaceous materials leading to high ORR overpotential.

In this report, we aimed to seek for the highly active and durable non-precious electrocatalyst to replace the expensive $\mathrm{Pt}$ catalyst under neutral condition. The synthesized catalyst with high porosity was thermally prepared at high temperature under autogenic pressure method without using any inert gas or ammonia atmosphere. The ORR activity of the M-N-C catalyst under neutral media was measured using rotating disk electrode (RDE) analysis. The ORR performance of the synthesized catalyst was compared to that of the noble $\mathrm{Pt} / \mathrm{C}$ catalyst. The novelty of this research was the electrochemical ORR performance under neutral media of the M-N-C catalyst fabricated using an autogenic pressure method which has not been reported to date.

\section{Experiments}

\subsection{Preparation of electrocatalysts}

The catalyst precursor was firstly prepared by refluxing melamine $(3.5 \mathrm{~g})$, iron acetate $(1.0 \mathrm{~g})$ and oxidized carbon powder $(1.0 \mathrm{~g})$ in ethanol at $60^{\circ} \mathrm{C}$ overnight. The solvent was evaporated and the powder precursor was then transferred into a Swagelok union closed cell and subjected to thermal pyrolysis at $900^{\circ} \mathrm{C}$ for $1 \mathrm{~h}$ under an ambient atmosphere. The calcination process was carried out at a heating rate of $10^{\circ} \mathrm{C} / \mathrm{min}$. The heated sample was assigned to be " $\mathrm{Fe}_{3} \mathrm{C}$ ". The as-prepared catalyst with amount of $0.1 \mathrm{~g}$ was put in a vial contained $0.5 \mathrm{M}$ $\mathrm{H}_{2} \mathrm{SO}_{4}$. The admixture was heated at $90^{\circ} \mathrm{C}$ for $8 \mathrm{~h}$. The acid-treated sample was washed and dried overnight in a vacuum oven. Finally, the acid-treated sample was secondly carbonized using a Swagelok close cell at $900^{\circ} \mathrm{C}$ for $1 \mathrm{~h}$ under an ambient atmosphere. This catalyst was named "Fe-N-C"

\subsection{Physical characterizations}

Field-emission scanning electron microscope (FE-SEM, Hitachi S-4800II) with an accelerated voltage of $3 \mathrm{kV}$ was employed to investigate the morphology of samples. Please note that the sample was coated with osmium before SEM analysis. The phase analysis of samples was estimated using powder X-ray diffraction (XRD, PANanalytical-Empyrean) using $\mathrm{K} \alpha$ radiation and generation voltage of $40 \mathrm{kV}$. Surface area of samples was determined by Brunauer-Emmett-Teller technique (BET).

\subsection{Electrochemical characterizations}

Catalyst ink was prepared by ultrasonic mixing catalyst powder, DI-water, 5\% Nafion and Isopropyl alcohol followed the literature [18]. A working electrode was prepared by dropping catalyst ink on the surface of a clean glassy carbon and left it dry under ambient atmosphere. The catalyst loading on the working electrode was $0.5 \mathrm{mg} / \mathrm{cm}^{2}$ while the amount of reference sample which is $\mathrm{Pt} / \mathrm{C}$ was $60 \mu \mathrm{g} / \mathrm{cm}^{2}$. Working electrode was then connected into an electrochemical cell where $\mathrm{Pt}$ wire used as a counter electrode and saturated calomel electrode (SCE) used as reference electrode were also attached. The ORR catalytic activity of sample was evaluated under $\mathrm{O}_{2}$-saturated phosphate buffer saline (PBS) solution ( $\mathrm{pH} \mathrm{7)}$ rotating disk electrode (RDE) technique using Biologic, VSP.

\section{Results and discussion}

Fig. 1 represented the X-ray diffraction pattern of the $\mathrm{Fe}_{3} \mathrm{C}$ and $\mathrm{Fe}-\mathrm{N}-\mathrm{C}$ electrocatalysts. According to standard data base (JCPDS), peaks observed in $\mathrm{Fe}_{3} \mathrm{C}$ (Fig. 1a) were perfectly matched to cohenite $\left(\mathrm{Fe}_{3} \mathrm{C}\right)$ and carbon. While, peaks generated in the XRD pattern of $\mathrm{Fe}-\mathrm{N}-\mathrm{C}$ (Fig. 1b) corresponding to carbon. In addition, two broad 
peaks were observed at $2 \theta$ of 24.5 and 43.3 degree for Fe-N-C sample (Fig. 1b), indicating the typical graphitic $C(002)$ and $C(100)$ turbo static carbon structure [7]. The graphitic $\mathrm{C}(002)$ plane of the carbon was usually found at 26.9 degree. The negative shift of graphitic $\mathrm{C}(002)$ plane of the $\mathrm{Fe}_{3} \mathrm{C}$ and $\mathrm{Fe}-\mathrm{N}-\mathrm{C}$ catalysts suggested an increase in the interlayer-distance due to the incorporation of $\mathrm{N}$ and $\mathrm{Fe}$ in the carbon framework, leading to excellent electron mobility throughout the catalyst.

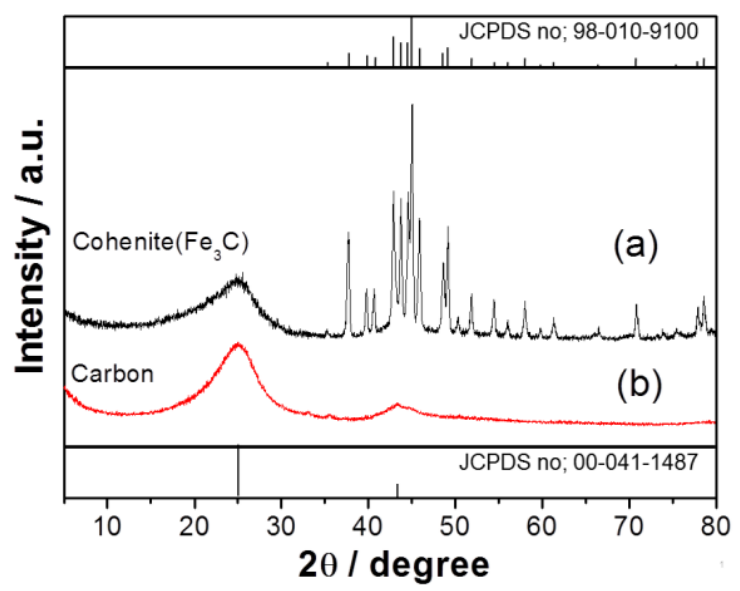

Fig. 1. $\mathrm{XRD}$ pattern of the $\mathrm{Fe}_{3} \mathrm{C}$ (a) and $\mathrm{Fe}-\mathrm{N}-\mathrm{C}$ (b) electrocatalysts.

Fig. 2 illustrated the morphology of the $\mathrm{Fe}_{3} \mathrm{C}$ and $\mathrm{Fe}-$ $\mathrm{N}-\mathrm{C}$ electrocatalysts observed by FE-SEM. SEM image of $\mathrm{Fe}_{3} \mathrm{C}$ catalyst showed nanoparticle morphology and high porosities. However, the particle size of the $\mathrm{Fe}_{3} \mathrm{C}$ catalyst was not uniform distribution and its particle size was found to be in the range of $40-600 \mathrm{~nm}$ (Fig. 2a). SEM image of Fe-N-C sample presented high porosities and uniform size distribution without agglomeration (Fig. 2b). An average particle sizes of the Fe-N-C samples was found to be $50 \mathrm{~nm}$. The larger particle size $\left(>100 \mathrm{~nm}\right.$ ) observed in $\mathrm{Fe}_{3} \mathrm{C}$ catalyst (Fig. 2a) may be the $\mathrm{Fe}_{3} \mathrm{C}$ and the small particle size $(30 \mathrm{~nm})$ corresponded to the VXC-72R carbon. The surface area of the $\mathrm{Fe}_{3} \mathrm{C}$ and $\mathrm{Fe}-\mathrm{N}-\mathrm{C}$ catalysts was evaluated by Brunauer-Emmett-Teller (BET) technique and BET surface area of $\mathrm{Fe}_{3} \mathrm{C}$ and $\mathrm{Fe}-\mathrm{N}-\mathrm{C}$ catalysts was calculated to be 295.7 and $377.5 \mathrm{~m}^{2} \mathrm{~g}^{-1}$, respectively (Table 1). It should be emphasized that pyrolysis of the $\mathrm{Fe}, \mathrm{N}$ and $\mathrm{C}$ precursors at $900{ }^{\circ} \mathrm{C}$ under autogenic pressure resulted in the formation of $\mathrm{Fe}_{3} \mathrm{C}, \mathrm{Fe}-\mathrm{N}_{\mathrm{x}}$ and doped $\mathrm{N}$ into the carbon structure [19-20] (Fig. 1a). On the other hand, iron carbide was chemically dissolved in $0.5 \mathrm{M} \mathrm{H}_{2} \mathrm{SO}_{4}$, remaining only carbon (Fig. 1b). X-ray photo electron spectroscope (XPS) was employed to verify the elemental composition of the Fe-N-C catalyst [18]. Elemental $\mathrm{Fe}, \mathrm{C}, \mathrm{O}$ and $\mathrm{N}$ were observed in XPS survey spectra [18]. The observed valence of $\mathrm{Fe}$ was $\mathrm{Fe}^{2+}$ which was able to bond with $\mathrm{N}$ forming $\mathrm{Fe}-\mathrm{N}_{\mathrm{x}}$ active site [18]. In addition, High resolution N1s spectra suggested the pyridinic, pyrolic and graphitic $\mathrm{N}$ functional group, confirming the incorporation of $\mathrm{N}$ into the carbon framework of Fe-N-C catalyst [18].

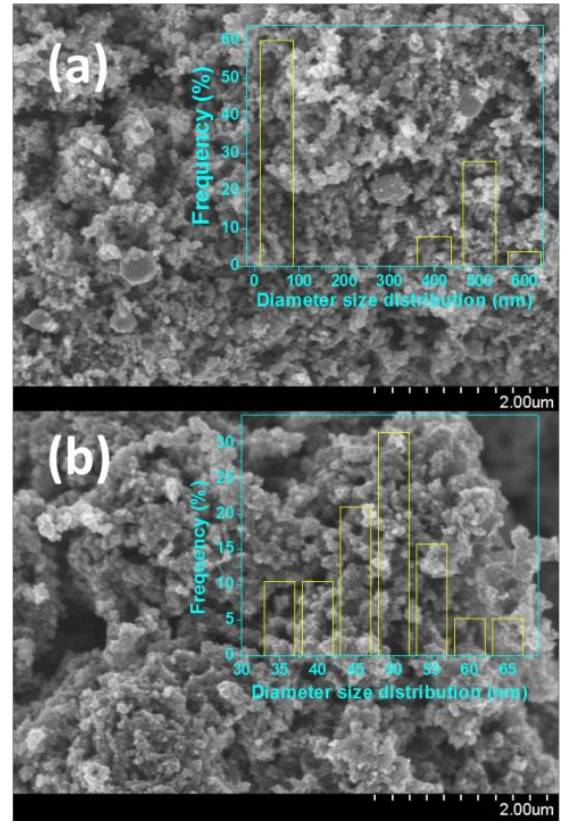

Fig. 2. FE-SEM image of $\mathrm{Fe}_{3} \mathrm{C}$ (a) and $\mathrm{Fe}-\mathrm{N}-\mathrm{C}$ (b) electrocatalysts.

The electrochemical ORR activity was performed using a rotating disk electrode (RDE) under $\mathrm{O}_{2}$-saturated PBS solution (pH 7) with a scan rate of $10 \mathrm{mV} / \mathrm{s}$ and the ORR result was compared to the ORR result of the commercial Pt/C (10 wt\% Johnson Matthey) (Fig. 3). Linear sweep voltammogram (LSV) plots of $\mathrm{Fe}_{3} \mathrm{C}$ and $\mathrm{Fe}-\mathrm{N}-\mathrm{C}$ catalysts recorded at a rotating speed of $1200-$ $2500 \mathrm{rpm}$ (Fig. 3a-b) showed that current density increased as the rotation speed was increased due to the shortening flux-diffusion. Fig. 3c compared the ORR performance of $\mathrm{Fe}_{3} \mathrm{C}$ and $\mathrm{Fe}-\mathrm{N}-\mathrm{C}$ electrocatalysts in comparison with the commercial $\mathrm{Pt} / \mathrm{C}$ at rotation speed of $1600 \mathrm{rpm}$ in neutral media solution. The ORR activity of $\mathrm{Fe}_{3} \mathrm{C}$ catalyst was poorer than the $\mathrm{Fe}-\mathrm{N}-\mathrm{C}$ catalyst. On the other hand, the Fe-N-C electrocatalyst exhibited comparable ORR performance to the noble $\mathrm{Pt} / \mathrm{C}$ catalyst. Table 1 represented the onset potential and steady state current density of the $\mathrm{Fe}_{3} \mathrm{C}$ and $\mathrm{Fe}-\mathrm{N}-\mathrm{C}$ catalysts in comparison with the $\mathrm{Pt} / \mathrm{C}$ catalyst. The onset potential of the $\mathrm{Fe}_{3} \mathrm{C}$ and $\mathrm{Fe}-\mathrm{N}-\mathrm{C}$ catalysts was 0.175 and $0.190 \mathrm{~V}$ vs. SCE, respectively. The onset potential of the commercial $\mathrm{Pt} / \mathrm{C}$ was $0.200 \mathrm{~V}$ vs SCE. The onset potential of the Fe-N-C catalyst was nearly the same as the precious $\mathrm{Pt} / \mathrm{C}$ catalyst. On the other hand, the steady state current density of the $\mathrm{Fe}_{3} \mathrm{C}, \mathrm{Fe}-\mathrm{N}-\mathrm{C}$ and $\mathrm{Pt} / \mathrm{C}$ catalysts was $-2.62, \quad-4.00$ and $-2.55 \mathrm{mAcm}^{-2}$, respectively. The steady state current density of the Fe$\mathrm{N}-\mathrm{C}$ catalyst was about 1.6 times higher than the precious $\mathrm{Pt} / \mathrm{C}$ catalyst. Furthermore, the ORR catalytic activity per catalyst cost of $\mathrm{Fe}-\mathrm{N}-\mathrm{C}$ was much higher than that of the Pt/C catalyst. The Koutecky-Levich (KL) plots shown in the insets in Fig. 3a and b were derived from the LSV plots and these plots exhibited good linearity and parallelism over all the potential range, indicating the first order reaction kinetics for the ORR [18]. The electron transfer number of the $\mathrm{Fe}_{3} \mathrm{C}$ and Fe-N-C catalyst at $0.5 \mathrm{~V}$ vs. SCE was calculated to be 2.9 and 3.7, respectively, suggesting the Fe-N-C catalyst 
possessed a direct four electron transfer but not for $\mathrm{Fe}_{3} \mathrm{C}$ catalyst. The superior ORR performance of the Fe-N-C relative to the $\mathrm{Fe}_{3} \mathrm{C}$ catalyst was mainly due to the presence of the more stable $\mathrm{OOH}$ species on the surface of $\mathrm{Fe}-\mathrm{N}-\mathrm{C}$ rather than $\mathrm{Fe}_{3} \mathrm{C}$ [19].

Table 1 Surface area, onset potential and steady state current density of electrocatalysts at $1600 \mathrm{rpm}$ under neutral $\mathrm{pH}$

\begin{tabular}{|c|c|c|c|}
\hline Catalyst & $\begin{array}{c}\text { Surface } \\
\text { area }\left(\mathrm{m}^{2} / \mathrm{g}\right)\end{array}$ & $\begin{array}{c}\text { Onset } \\
\text { potential } \\
(\mathrm{V} \text { vs SCE) } \\
\end{array}$ & $\begin{array}{c}\text { Steady state } \\
\text { current density } \\
\left(\mathrm{mA} \mathrm{cm} \mathbf{c m}^{-2}\right)\end{array}$ \\
\hline $\mathrm{Pt} / \mathrm{C}$ & $\mathrm{N} /$ & 0.200 & -2.55 \\
\hline $\mathrm{Fe}_{3} \mathrm{C}$ & 295.7 & 0.175 & -2.62 \\
\hline $\mathrm{Fe}-\mathrm{N}-\mathrm{C}$ & 377.5 & 0.190 & -4.00 \\
\hline
\end{tabular}

N/A was not available
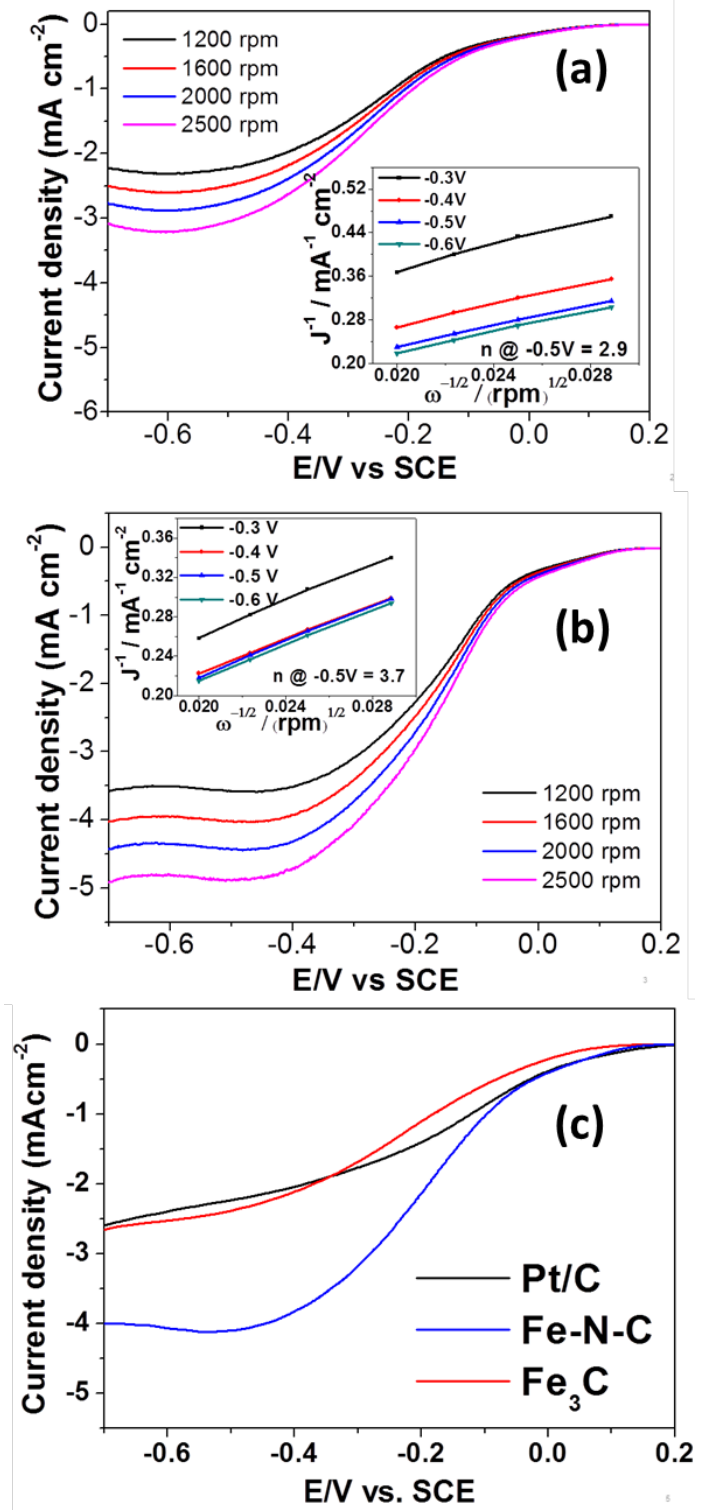

Fig. 3. ORR polarization curves of $\mathrm{Fe}_{3} \mathrm{C}$ catalyst (a), Fe-N-C catalyst (b) in an $\mathrm{O}_{2}$-saturated PBS media at different rotation speed (insets in (a) and (b) are Koutecky-Levich plots of $\mathrm{Fe}_{3} \mathrm{C}$ and $\mathrm{Fe}-\mathrm{N}-\mathrm{C}$ catalysts, respectively). (c) comparison of LSV plots of $\mathrm{Fe}_{3} \mathrm{C}, \mathrm{Fe}-\mathrm{N}-\mathrm{C}$ and $\mathrm{Pt} / \mathrm{C}$ catalysts under $\mathrm{O}_{2}$-saturated PBS media.
It has been reported that ORR mechanism are involved in the $\mathrm{OOH}$ species on the surface of the catalyst. The $\mathrm{OOH}$ species further generates $\mathrm{O}^{*}$ species and electrochemically reduced to $-\mathrm{OH}$ species and finally production of water [19]. Furthermore, the outstanding ORR catalytic activity of Fe-N-C electrocatalyst was mainly thanks to the incorporation of $\mathrm{N}$ into $\mathrm{C}$ framework as well as the formation of $\mathrm{Fe}-\mathrm{N}_{\mathrm{x}}$ which was efficiently increased binding capabilities of oxygen and higher ionization potentials [18]. In order to determine the outstanding catalyst synthesis technique, we compared ORR performance of the Fe-N-C catalyst prepared using autogenic pressure method with conventional method. The ORR performance of the prepared Fe-N-C catalyst was much superior to that of activation carbon [15], graphene nanosheet [15], Ndoped carbon nanoparticle [7], $\mathrm{N}$ and $\mathrm{B}$ codoped carbon nanoparticle [7] catalysts. Compare to M-N-C catalyst, the fabricated $\mathrm{Fe}-\mathrm{N}-\mathrm{C}$ catalyst generated higher ORR performance than that of NiAApyr [13], MnAApyr [13], CoAApyr [13], Fe-Quinine [14], Fe-sulfadiazene [14], FeAc/Vulcan XC-72R [16] catalysts. This information suggested that an autogenic pressure method was a promising technique to fabricate a highly active ORR catalyst operated under neutral media.

Fig. 4 presented the chronoamperometric response of the Fe-N-C catalyst compared to the commercial $\mathrm{Pt} / \mathrm{C}$ catalyst at $0.05 \mathrm{~V}$ vs. SCE under $\mathrm{O}_{2}$ saturated neutral media. It was found that the current of the Fe-N-C catalyst at initial was $-0.0431 \mathrm{~mA}$ and the current was decay to $-0.0435 \mathrm{~mA}$ after $10,000 \mathrm{~s}$ at $0.05 \mathrm{~V}$ vs. SCE. On the other hand, the current of the $\mathrm{Pt} / \mathrm{C}$ catalyst at the beginning was $-0.0422 \mathrm{~mA}$ and the current remained $-0.046 \mathrm{~mA}$ after $10,000 \mathrm{~s}$ operation at $0.05 \mathrm{~V}$ vs. SCE. After $10,000 \mathrm{~s}$ operation, the current of the Fe-N-C catalyst decay $0.9 \%$, while the decay current of $\mathrm{Pt} / \mathrm{C}$ catalyst was $10 \%$. The decay current of $\mathrm{Pt} / \mathrm{C}$ catalyst was faster than the $\mathrm{Fe}-\mathrm{N}-\mathrm{C}$ catalyst. These results suggest that the Fe-N-C catalyst was durable to operate under neural media and showed promising an ORR electrocatalyst to replace the expensive $\mathrm{Pt} / \mathrm{C}$ catalyst for microbial fuel cells.

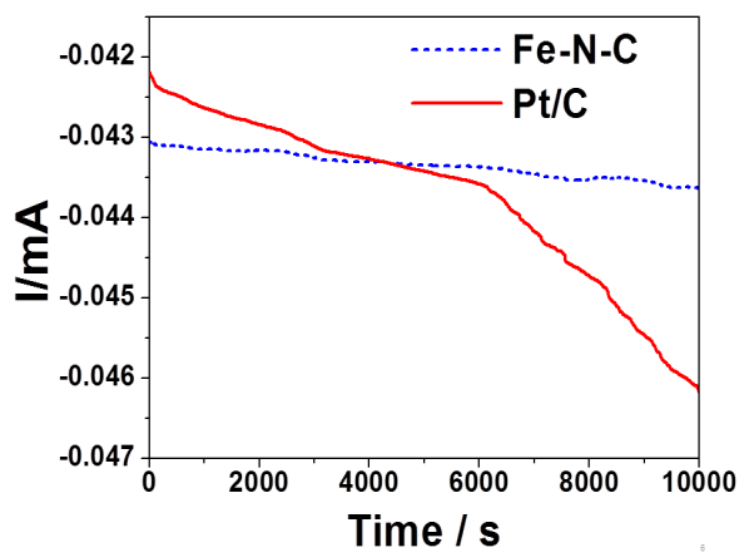

Fig. 4. Durability test of the $\mathrm{Fe}-\mathrm{N}-\mathrm{C}$ and $\mathrm{Pt} / \mathrm{C}$ catalysts under $\mathrm{O}_{2}$-saturated PBS media at $0.05 \mathrm{~V}$ vs. SCE. 


\section{Conclusion}

We demonstrated that non-precious metal coordinated nitrogen doped carbon catalyst fabricated using an autogenic pressure method exhibited highly active and durable ORR in PBS media ( $\mathrm{pH} 7$ ). Especially, Fe-N-C catalyst showed superior ORR performance relative to the state of the art $\mathrm{Pt} / \mathrm{C}$ catalyst. In addition, the ORR activity of the $\mathrm{Fe}-\mathrm{N}-\mathrm{C}$ catalyst was stable during operation under neutral $\mathrm{pH}$.

This research was funded by King Mongkut's University of Technology North Bangkok. Contract no. KMUTNB-62-NEW-07

\section{Reference}

1. C. Santoro, C. Arbizzani, B. Erable, I. Ieropoulos, J. Power Sources. 356, 225 (2017)

2. M. Rahimnejad, A. Adhmi, S. Darvari, A. Zirepour, S. Oh, Alexandria Eng. J. 54, 745 (2015)

3. C. Santoro, A. Serov, L. Stariha, M. Kodali, J. Gordon, S. Babanova, O. Bretschger, K. Artyushkova, P. Atanssov, Energy \& Environ. Sci. 9, 2346 (2016)

4. J. Wei, P. Liang, X. Huang, Bioresour. Technol. 102, 9335 (2011)

5. M. Mustakeem, Mater. Renew. Sustain. Energy. 4, 22 (2015)

6. D. Qazzazie, M. Beckert, R. Mulhaupt, O. Yurchenko, G. Urban, Electrochi Acta. 186, 579 (2015)
7. S. Zhong, L. Zhou, L. Wu, L. Tang, Q. He, J. Ahmed, J. Power Sources. 272, 344 (2014)

8. Z. Wang, G. D. Mahadevan, Y. Wu, F. Zhao, J. Power Sources. 356, 245 (2017)

9. D-W. Wang, D. Su, Energy \& Environ. Sci. 7576 (2014)

10. K. Gong, F. Du, Z. Xia, M. Durstock, L. Dai, Science. 323, 760 (2009)

11. G. Wu, K. L. More, C. M. Johnston, P. Zelenay, Science. 332, 443 (2011)

12. M. Kodali, C. Santoro, S. Herrera, A. Serov, P. Atanassov, J. Power Sources 366, 18 (2017)

13. S. Rojas-Carbonell, C. Santoro, A. Serov, P. Atanassov, Electrochem. Commun. 75, 38 (2017)

14. C. Santoro, A. Serov, R. Gokhale, S. R. Carbonell, L. Stariha, J. Gordon, K. Artyushkova, P. Atanassov, Appl. Catal. B- Environ. 205, 24 (2017)

15. M. Kodali, S. Herrera, S Kabir, A. Serov, C. Santoro, I. Ieropoulos, P. Atanassov, Electrochim. Acta. 265, 56 (2018)

16. L. Birrya, P. Mehtab, F. Jaouena, J.-P. Dodeleta, S.R. Guiotb, B. Tartakovsky, Electrochim Acta. 56, 1505 (2011)

17. Z.-Y. Yang, Y.-X. Zhang, L. Jing, Y.-F. Zhao, Y.-M. Yan, K.-N. Sun, J. Mater. Chem. A, 2, 2623 (2014).

18. J. Senetuntikul, S. Shanmugam, Nanoscale. 7, 7644 (2015)

19. M-Q. Wang, C. Ye, M. Wang, T-H. Li, Y-N. Yu, S-J. Bao, Energy Storage Mater. 11, 112-117 (2018)

20. Z. Chen, Z. Gao, X. Wei, X. Wang, Y. Li, T. Wu, J. Guo, Q. Gu, W. D. Wu, X. D. Chen, Z. Wu, D. Zhao, Carbon. 121, 143 (2017) 